\title{
Monipuolinen kokoomateos sosiolingvistisistä paneelitutkimuksista
}

Suzanne Evans Wagner \& Isabelle Buchstaller (toim.): Panel studies of variation and change. Routledge Studies in Language Change 1. London: Routledge 2018. 294 s. ISBN 978-1-138-90390-6.

Tällä vuosituhannella sosiolingvistisessä variaationtutkimuksessa yhtenä keskeisenä näkökulmana on ollut muutoksen reaaliaikainen tarkastelu. Reaaliaikatutkimuksen lisääntyminen ei yllätä, sillä labovilaisen sosiolingvistiikan kypsyminen noin 50 vuoden ikään tarkoittaa sitä, että aiemmin kerättyä vertailukelpoista aineistoa on jo runsaasti saatavilla. Sosiolingvistiset reaaliaikatutkimukset jaetaan kahteen tyyppiin: paneelitutkimuksessa seurataan saman yksilön tai yksilöiden kieltä, trenditutkimuksen idea taas on valita tutkittavat eri aikoina samoin kriteerein. Monissa tutkimuksissa näitä näkökulmia on yhdistetty niin, että samojen yksilöiden seuraamisen lisäksi myöhempiä otantoja on täydennetty nuorta sukupolvea edustavalla uudella ikäryhmällä tai etsimällä seurannasta tipahtaneiden tilalle uusia informantteja (esim. Kurki 2005: 67-74; Paunonen 2005: 165; 2018: 23-28; Sundgren 2004: 65-76).

Suzanne Evans Wagnerin ja Isabelle Buchstallerin toimittamassa teoksessa esitellään ensi kertaa kokoavasti erilaisia sosiolingvistisiä paneelitutkimuksia. Artikkelikokoelma pohjaa Methods in dialectology $X V$-konferenssissa vuonna 2014 järjestettyyn paneeliin. On harmillista, ettei paneelissa tietojemme mukaan ollut suomalaisedustusta eikä Suomessa tehty reaaliaikatutkimus sen vuoksi juuri näy artikkelikokoelmassa.

Teos muodostuu Wagnerin ja Buchstallerin kirjoittamasta johdannosta, jossa taustoitetaan aihetta ja esitellään artikkelit, sekä kymmenestä tutkimusartikkelista, jotka on jaoteltu neljään temaattiseen kokonaisuuteen. Vaikka teoksessa on hajanaisuutta ja päällekkäisyyttä, jota temaattinen järjestely ei täysin pysty häivyttämään, esittelymme etenee kokonaisrakenteen mukaisesti. Lopuksi nostamme esiin muutamia yleisiä ja ajankohtaisia huomioita.

\section{Reaaliaikainen paneelitutkimus: koko kuva}

Vaikka jo William Labov kyseenalaisti idiolektien stabiiliuden ja niin sanotun kriittisen iän hypoteesin, variaationanalyysi rakentui pitkään näennäisaikatutkimukselle, jonka lähtökohta on idiolektien muuttumattomuus nuoruusvuosien jälkeen ja se, että kukin sukupolvi edustaa oman nuoruusaikansa mukaista kielenmuutoksen vaihetta (ks. Laasanen 2016). Kirjan johdannossa toimittajat muistuttavat aiheellisesti, että maailmanlaajuisesti reaaliaikatutkimuksessa ovat olleet vallalla trenditutkimukset, mikä puoltaa paneelitutkimuksiin syventymistä ja näin idiolektinäkökulman lähempää tarkastelua.

Yksittäisten puhujien tarkastelu saattaa tuntua kapealta näkökulmalta, kun tutkimuskohteena on kielen muutos. Siksi yksilöitä koskevia tuloksia pyritäänkin yleensä peilaamaan laajempaan kokonaisuuteen, esimerkiksi eri aikoina tehtyihin näennäisaikatutkimuksiin (esim. Brook, Jankowski, Konnelly \& Tagliamonte 2018). Näin voidaan pohtia esimerkiksi sitä, ovatko yksilön kielessä mahdollisesti tapahtuneet muutokset samansuuntaisia kuin yhteisössä meneillään olevat 
trendit vai onko muutos toisensuuntaista. Kirjoittajat myöntävät, että myös isompia puhujamääriä koskeville tutkimuksille olisi tarvetta.

Johdannon jatkoksi sopii teoksen ensimmäisen osan "Methodological conundrums in building, sharing and analyzing panel corpora" aloittava Gillian Sankoffin artikkeli, jossa hän esittelee yhtä ensimmäisistä laajamittaisista reaaliaikatutkimuksista. Artikkeli sisältää hyödyllistä, kirjoittajan omakohtaisiin kokemuksiin perustuvaa tietoa siitä, millaisia vaiheita reaaliaikaiseen tutkimushankkeeseen kuuluu aina sen valmistelusta lähtien. Hän korostaakin dokumentoinnin tärkeyttä, kun kyseessä on vuosikymmenten mittainen pitkittäistutkimus. Montrealin ranskankielisiä koskeva hanke käynnistyi 1970-luvulla, ja sen seuraavat kierrokset toteutettiin 1980- ja 1990-luvuilla. Ensimmäisellä kierroksella tutkittavia valittiin peräti 120. Sankoff pitää otoksen suuruutta tärkeänä, jotta seuraavilla kierroksilla on riittävä pohja jatkaa. Toisella kierroksella tästä joukosta tavoitettiin puolet, ja samalla otettiin mukaan uusi nuorten ryhmä. Kolmannessa vaiheessa, 1990-luvulla, mukana oli 12 alkuperäistä informanttia sekä kaksi 1980-luvulla mukaan tullutta nuorta.

Tutkimusasetelmat, joissa aineistoa on kerätty vähintään kolmelta eri vuosikymmeneltä, eivät ole olleet toistaiseksi tavallisia (ks. kuitenkin esim. Palander 2005, 2016, 2018; Kuparinen 2018). Monet Montrealin hankkeessa tehdyt havainnot pätevät Suomessakin. Esimerkiksi mitä useampi kierros, sitä vinoutuneempi paneelitutkimuksen informanttijakauma on, koska alimmista sosiaaliryhmistä on ollut vaikeampaa tavoittaa haastateltavia uudestaan (Lappalainen, Mustanoja \& O'Dell tulossa).

Christopher Cieri ja Malcah YaegerDror muistuttavat omassa artikkelissaan, ettei tutkijoiden aina tarvitse itse kerätä alusta asti aineistoa vaan olemassa on pal- jon korpuksia, jotka soveltuvat ainakin periaatteessa paneelitutkimukseen. Tällaisten aineistojen avulla voidaan myös voittaa joitakin perinteiselle reaaliaikatutkimukselle tyypillisiä haasteita, joista monet liittyvät aiemmin mukana olleiden informanttien tavoittamiseen: yksi ei ole halukas enää osallistumaan, toinen on kuollut ja kolmannen nimi on vaihtunut eikä häntä onnistuta jäljittämään. Yksilön elämässä on myös saattanut tapahtua niin huomattavia muutoksia, että on syytä pohtia, edustaako hän enää ryhmää, johon hän on alun perin kuulunut.

Kokoomateoksen ensimmäisen osan päättää Janneke Van Hofwegen ja Walt Wolframin artikkeli. Heidän esittelemässään projektissa tutkittiin, onko löydettävissä joitain ikävaiheita, jolloin afroamerikkalaisen varieteetin eli AAL:n (African American Language) käyttö on erityisen vahvaa tai heikkoa. Tutkijat selvittivät myös, onko informanttien kielessä nähtävissä selvä kehitys kohti AAL:n tai standardienglannin vahvistumista ja voidaanko erottaa erilaisia malleja siitä, miten kyseiset varieteetit saavat jalansijaa. Lisäksi projektissa tarkasteltiin, mitkä ovat ensisijaiset sosiaaliset, psykologiset ja kasvatukseen liittyvät tekijät, jotka korreloivat AAL:n käytön kanssa eri elämänvaiheissa. Tämän 1990-luvulla alkaneen hankkeen yhteydessä tallennettiin monenlaista aineistoa: keskustelunomaista vuorovaikutusta, informanttien ja vanhempien haastatteluja, erilaisia testejä sekä taustatietoja kustakin ikävaiheesta. Sosiolingvististä variaatiota ja muutosta mittaamaan kehitettiin yhdistelmäindeksi (Dialect Density Measure), jonka tarkoituksena on tarjota kokonaisvaltainen kuva varieteetista. Siihen on koodattu tietoa yli 40 morfosyntaktisesta ja fonologisesta piirteestä, jotka ovat olennaisia AAL:n ja standardin välisen suhteen näkökulmasta. Kirjoittajien mukaan tämä indeksi antaa nopean tilannekuvan kunkin puhujan variaatiosta ja ottaa huo- 
mioon tallenteiden erilaiset pituudet ynnä muut ajalliseen vaihteluun liittyvät muuttujat, ja sen ansiosta on mahdollista vertailla niin samaa puhujaa eri ikävaiheissa kuin eri puhujia keskenään samassa ikävaiheessa. Tällainen muuttujien huomiointi onkin erityisen tärkeää pitkittäistutkimuksissa.

\section{Ikä biologisena ja sosiaalisena taustatekijänä}

Kirjan toisen osan "Key life stage events across the lifespan" aloittavassa artikkelissa Mary Kohn ja Charlie Farrington tarkastelevat vokaalien ääntämyksessä havaittavaa variaatiota lapsuus- ja nuoruusiässä sosiofoneettisesta näkökulmasta. Tutkimuksen aineistona on 20 nuorta, joita äänitettiin 10:n, 14:n, 16:n ja 20 vuoden ikäisinä. Kullakin keruujaksolla tallennettiin sekä muodolliseksi että epämuodolliseksi määriteltyä aineistoa: keskustelua äidin tai ikätoverin kanssa sekä ääneenluentaa, lauseiden toistoa tai tarkemmin määrittelemätöntä puhetta (performance of a speech).

Aineistoa saatiin niin yksilön kielen kehityksen kuin fysiologisen kehityksen kannalta varsin dynaamiselta ajanjaksolta: esimurrosikäisiltä, murrosikäisiltä ja nuoruusiän jo ainakin fysiologisesta näkökulmasta ohittaneilta informanteilta. Tutkimusmetodiikan kannalta ajanjakso on haastava, sillä fysiologinen kehitys tapahtuu samanaikaisesti sosiolingvististen muutosten kanssa. Kysymys onkin, miten tällaisessa tapauksessa saadaan kiinni sosiaaliseksi luokiteltavissa olevasta muutoksesta ja variaatiosta. Artikkelin keskeinen argumentti on, että lapsuus- ja nuoruusajan aineistoa on metodologisista haasteista huolimatta mahdollista sisällyttää pitkittäistutkimukseen, kunhan ääntöelimistön kehitys otetaan huomioon.

Toinen olennainen seikka on sopivien tilastomenetelmien löytäminen. Sosio- lingvistisissä mittauksiin ja tilastomenetelmiin perustuvissa tutkimuksissa käytetään tavallisesti normalisointia kontrolloimaan fyysisten erojen vaikutusta akustisiin korrelaatteihin. Näitä tarvitaan esimerkiksi silloin, kun tutkimusasetelmassa on mukana sekä mies- että naispuhujia. Samankaltaisia normalisointimenetelmiä on mahdollista soveltaa myös aikuis- ja lapsipuhujia sisältävään aineistoon, joskin vertailussa on oltava varovainen, etteivät käytetyistä menetelmistä johtuvat epävarmuustekijät heijastu virheinä johtopäätöksiin. Yhtä olennaista on, ettei epähuomiossa normalisoida näkymättömiin sellaista tietoa, joka onkin olennaista esimerkiksi äänteenmuutosten kannalta. Kohnin ja Farringtonin esittämät yksityiskohtaiset esimerkit vertailun ongelmista osoittavat erityisesti sen, että 1) tutkijan on tärkeää olla perillä käyttämänsä aineiston erityislaadusta ja käyttämiensä menetelmien rajoituksista ja että 2) aikaisempien tutkimusten tuottama tieto on usein monin tavoin käyttökelpoista uusien tutkimusasetelmien luomisessa, sillä monet kehityskuluista pystytään ennustamaan ja siten myös kontrolloimaan tuloksia tulkittaessa.

Kohn ja Farrington nostavat esiin myös jokaiselle lapsia haastatelleelle sosiolingvistille tuttuja käytännön ongelmia: Tarkasteltavien ilmiöiden esiintymämäärät saattavat jäädä vähäisiksi, jos lapsi ei ole puheliaalla tuulella. Äänitteistä saattaa myös tulla teknisesti huonolaatuisia, esimerkiksi hiljaisia tai muuten epäselviä. Onnistuneena kotimaisena esimerkkinä voidaan kuitenkin mainita Palanderin (2005) pitkittäistutkimus, jossa pääinformantti $\mathrm{Pa}$ sia on haastateltu ensimmäisen kerran jo seitsemänvuotiaana. 200o-luvulla $\mathrm{Pa}$ lander (2016) on ottanut tutkimukseen mukaan Pasin kaksospojat, jotka ensimmäisen haastattelun aikaan olivat isänsä tavoin vasta 7-vuotiaita. Eri-ikäsiä lapsia 
on haastateltu myös Kotimaisten kielten (silloisen tutkimus)keskuksen murteenseuruhankkeeseen (Nuolijärvi \& Sorjonen 2005: 26).

Vastaavien haasteiden parissa ei Ulrich Reuboldin ja Jonathan Harringtonin, osion toisen artikkelin kirjoittajien, ole tarvinnut painiskella. Heidän tutkimuksensa kohteena on Ison-Britannian kuningatar Elisabeth II (s. 1926) ja saksalainen uutisankkuri Dagmar Berghoff (s. 1943). Verrokkina toimii brittiläissyntyinen, sittemmin Yhdysvaltoihin muuttanut toimittaja Alistair Cooke (1908-2004). Kaikki aineistot perustuvat henkilöiltä taltioituihin julkisiin puheisiin tai tv-esiintymisiin. Materiaalia on seuruun näkökulmasta huomattavan pitkältä ajalta: kuningattarelta 26-vuotiaasta 76-vuotiaaksi, Berghoffilta 33-vuotiaasta 70-vuotiaaksi ja Cookelta 38-vuotiaasta peräti 95 -vuotiaaksi.

Tutkimuksen tavoitteena on selvittää, miten ikääntymiseen liittyvät muutokset voidaan erottaa sosiofoneettisista muutoksista. Tulokset nostavat esiin sekä yksilöllisen variaation ja liikkumavaran että fysiologiset, väistämättömät muutokset. Tunnettua on, että esimerkiksi äänenkorkeus kääntyy nousuun 60 ikävuoden tienoilla. Kuitenkin Berghoffilla tätä indikoivat mittaustulokset ovat erilaiset kuin kahdella muulla ikääntyvällä tutkimushenkilöllä. Kirjoittajat olettavat tämän johtuvan siitä, että hän on koulutettu äänenkäyttäjä ja pystyy näin paremmin kontrolloimaan puhettaan fysiologian asettamien raamien sisällä. Kiinnostava havainto on myös Cookella iän myötä tapahtuva aksentin paluu, siis selvä fysiologiasta riippumaton muutos. Myös Tampereen puhekielen paneelitutkimuksessa (Mustanoja 2011: 347) havaittiin aineiston iäkkäimmällä puhujalla murteellistumista ikävuosien 70 ja 90 välillä. Reuboldin ja Harringtonin havaintojen mukaan vanhalla iällä palataan nimenomaan vahvimmin juurtuneeseen puhetapaan samalla, kun mukautuminen puhekumppaniin vähenee.

\section{Eriaikaisten aineistojen vertailukelpoisuus}

Kolmannen osan "Stylistic determinants of linguistic malleability" aloittaa Frans Gregersenin, Torben Joel Jensenin ja Nicolai Pharaon artikkeli, jossa he pohtivat tanskankielisen aineiston valossa, miten tunnistaa todellinen muutos tilanteisesta vaihtelusta. Heidän ratkaisunsa on diskurssikontekstin analyysi (discourse context analysis, DCA). Tutkimus perustuu laajasta LANCHART-korpuksesta rajattuun 179 haastattelun aineistoon, jossa on mukana 94 eri puhujaa.

Tutkijat ovat koodanneet koko aineiston suhteessa kuuteen muuttujaan: 1) kenen ääni kuuluu (onko kyseessä esim. referointi), 2) makropuheaktin tyyppi eli mikä on katkelman pääfunktio (esim. tiedon vaihto, asenteiden ilmaisu), 3) puhetilanteen tyyppi (esim. yksilöhaastattelu vs. ryhmähaastattelu), 4) genre (esim. kertomus, juoru), 5) vuorovaikutuksen rakentuminen siltä kannalta, kuka on siitä vastuussa (esim. käänteiset vuorovaikutusroolit, jolloin haastateltava esittää kysymyksiä haastattelijalle) ja 6) haastattelun vaihe (esim. henkilötietojen kysely). Kirjoittajat myöntävät, että kategoriat ovat keskenään varsin erilaisia: osa on ilmeisiä, osan määrittely on tulkinnanvaraisempaa.

Artikkelissa esitellään kaksi DCAmallin sovellusta, joista toinen kohdistuu yhteen yksilöön, toinen koko aineistoon. Tavoitteena on testata, onko tutkituissa piirteissä tapahtunut todellista reaaliaikaista muutosta vai onko kyse tilanteisesta vaihtelusta. Ensimmäisen tapaustutkimuksen informantti on osallistunut kahtena eri ajankohtana yksilöhaastatteluun ja ensimmäisellä kierroksella lisäksi ryhmähaastatteluun. Tästä aineistosta on koodattu vain ne kohdat, jotka edustavat 
selvästi jotakin genreä (4), eli osa materiaalista on jätetty koodauksen ja tarkastelun ulkopuolelle. Näin päästään vertailemaan toisaalta saman haastattelun erilaisia genrejä toisiinsa, toisaalta eriaikaisia samaa genreä edustavia katkelmia keskenään.

Tapaustutkimus näyttää, että ajalliset muutokset ovat nimenomaan tiettyyn genreen liittyviä: koko haastattelua tarkastellen tutkitussa foneettisessa piirteessä ei ole havaittavissa tilastollisesti merkitsevää eroa, kun taas genreittäin eritellen muutos on todennettavissa. Ilman tällaista hienojakoista analyysitapaa muutos olisi siis jäänyt havaitsematta. Ryhmähaastattelun mukaan otto kuitenkin mutkistaa tulkintojen tekemistä, sillä siinä vastaavaa genre-eroa ei ilmene. Yleistyksiä onkin tehtävä varoen, sillä esimerkiksi puhekumppanilla saattaa olla vaikutusta. Toinen esimerkki koskee geneerisesti käytettyjen pronominien ( $d u$ vs. man/en) käyttöä koko aineistossa. Haasteeksi tilastollisessa analyysissa paljastuu, että osa diskurssianalyysin kategorioista on hyvin harvinaisia. Monimuuttuja-analyysissa käy kuitenkin ilmi, että kaikki DCAmallin kategoriat, toimintatyyppiä (6) lukuun ottamatta, ovat tilastollisesti merkitseviä, kun selitetään aineistossa ilmenevää variaatiota.

Kirjoittajat toteavat, että diskurssikontekstin analyysille on tarvetta etenkin silloin, kun vertailtavat haastattelut eroavat toisistaan useammassa kuin yhdessä suhteessa. Näin on mahdollista kontrolloida muuttujia ja sulkea pois tilanteinen vaihtelu. Mutkikkaammaksi tilanne käy silloin, jos vanhempi aineisto on kerätty hyvin erilaisin periaattein kuin uudempi kysymys, johon on törmätty Suomessakin, kun sosiolingvististen haastattelujen verrokiksi on otettu vanhaa Suomen kielen nauhoitearkiston aineistoa. Kirjoittajat muistuttavat, ettei tässä esitelty malli sovellu suoraan muihin aineistoihin, vaan kulloinkin on pohdittava, millai- nen koodaaminen on mielekästä ja kannattavaa. Suomessa vastaavaa ei ole toistaiseksi tehty, mutta Mustanojan (2011) väitöskirjassaan soveltaman ikkunametodin takana on sama ajatus - pyrkimys löytää keskenään vertailukelpoisia katkelmia eriaikaisista haastatteluista.

Kahdessa seuraavassa artikkelissa esitellään paneelitutkimuksia, joissa yksilöiden seuranta on ollut hyvin intensiivistä. Patricia Cukor-Avilan ja Guy Baileyn artikkelissaan esittelemä Springvillen projekti on toiminut vuodesta 1988 , ja siinä tutkimuskohteena on teksasilainen pikkukylä. Osa vuosina 1894-2002 syntyneistä informanteista on ymmärrettävästi jo kuollut, osa muuttanut pois, osa asunut muualla ja sitten taas palannut. Haastatteluja projektiin on tehty lähes joka vuosi, ja samat tutkijat ovat olleet koko ajan mukana. Kaikkiaan korpuksessa on yli 2000 ooo sanaa.

Artikkelin keskiössä on kaksi idiolektien seuruun haastetta: joidenkin tarkasteltavien varianttien pieni frekvenssi sekä tutkijan ja tutkittavien välisen suhteen kiinteyden heijastuminen tuloksiin ( gap effect). Näistä jälkimmäinen on kytköksissä myös haastattelujen välillä kuluneeseen aikaan ja kietoutuu vahvasti haastattelun tilannevariaation huomioimiseen (vrt. Gregersenin ym. artikkeliin). Sekä pieni frekvenssi että eriaikaisten haastattelujen tilannevariaatio ovat paneelitutkimukseen perustavanlaatuisesti liittyviä ilmiöitä, joita ei ole mahdollista siivota pois. Tämä ei kuitenkaan tarkoita, että ne pitäisi sivuuttaa, sillä vaikutus tuloksiin voi olla dramaattinen.

Artikkeli havainnollistaa, kuinka helposti yksioikoiset päätelmät voivat vääristää kuvaa muutoksesta. Kirjoittajat esittävät, että monet aineistojen välillä havaittavista eroista selittyvät nimenomaan varianttien vähäisillä esiintymämäärillä. Kun tarkastelussa ovat haastattelut, joissa esiintymiä on paljon, erot tasoittuvat. Niukemmista aineistoista tehtävät virhe- 
päätelmät voidaan artikkelin mukaan välttää esimerkiksi sillä, että ajallisesti lähekkäin tehtyjen haastattelujen esiintymät lasketaan yhteen ja näin yksittäisten varianttien frekvenssi saadaan kasvamaan. On kuitenkin aiheellista huomauttaa, että piirteiden pieni frekvenssi ei estä luotettavaa, tilastomenetelmiin perustuvaa muutoksen arviointia. Frekventeissä piirteissä havaittavat pienetkin erot taas saattavat olla tilastollisesti merkitseviä. (Ks. esim. Mustanoja 2011: 79-80, 95-103; Lappalainen ym. tulossa).

Tutkijan ja tutkittavien välinen suhde on tarkastelussa myös Suzanne Evans Wagnerin ja Sali A. Tagliamonten artikkelissa. Artikkelissa esiteltyjen paneelitutkimusten päätavoitteena on selvittää, onko aika merkittävä muutosten ennustaja, kun nuori aikuistuu. Eriaikaisten aineistojen erot saattavat kuitenkin liittyä enemmän haastattelijan vaikutukseen kuin kertoa todellisesta muutoksesta. Silti toistaiseksi on varsin vähän tutkimuksia, joissa tätä olennaista muuttujaa eli haastattelijaa ei olisi mukana. Tämä johtunee informanttien itse tekemiin tallennuksiin liittyvistä eettisistä ongelmista sekä vaikeudesta kontrolloida puheenaiheita ja tallennusolosuhteita, mistä seuraa aineiston käsittelyn hitaus ja vaikea vertailtavuus. Sen sijaan haastateltavan ja haastattelijan suhteeseen liittyvää statuseroa on pyritty vähentämään tutkijan osallistuvalla havainnoinnilla (ks. esim. Tetreaultin artikkelia, joka esitellään seuraavassa alaluvussa) sekä käyttämällä samaa tai mahdollisimman samankaltaista haastattelijaa eri haastattelukerroilla. Wagner ja Tagliamonte kuitenkin huomauttavat, että samaakin haastattelijaa käytettäessä osallistujien keskinäisessä suhteessa tapahtuu väistämättä muutoksia.

Kirjoittajat tarkastelevat näitä kysymyksiä kahden pitkittäistutkimuksen kautta, joissa molemmissa tutkittavat ovat nuoria pohjoisamerikkalaisia naisia. Wag- nerin aineisto on kerätty Philadelphiasta vuosina 2005-2012, ja siinä on mukana terveydenhoitoalalla opiskelevia ja sieltä valmistuneita naisia. Alussa mukana olleista 66 puhujasta kolmannella haastattelukerralla oli mukana vielä 14. Tagliamonten tutkimuskohteena on puolestaan torontolainen "Clara", jota hänen isosiskonsa on haastatellut vuodesta 2002 lähes joka vuosi (ks. myös Brook ym. 2018).

Kirjoittajien mukaan molemmissa tutkimuksissa oli havaittavissa muutoksia haastattelijan ja haastateltavan välisessä suhteessa niin, että etäisyys väheni ajan myötä. Suhteen muutos voi olla analyysin kannalta ongelmallista kolmella tavalla: se voi vaikuttaa 1 ) haastateltavan puhetyyliin ja asennoitumiseen, 2) haastattelun sisältöön sekä 3) vuorovaikutuksen luonteeseen niin, että haastattelijan oma osuus kasvaa, koska haastateltava alkaa odottaa myös haastattelijan jakavan omia kokemuksiaan. Kirjoittajien ehdotus viimeiseen haasteeseen on niinkin yksinkertainen, että haastattelija kertoisi omia kuulumisiaan varsinaisen haastattelun ulkopuolella.

\section{Reaaliaikainen paneelitutkimus lähi- tieteenaloilla}

Chantal Tetreault tarkastelee viimeisen osan "Interdisciplinary approaches" aloittavassa artikkelissaan paneeli- ja pitkittäistutkimuksia etnografin silmin. Kysymys tutkijan ja tutkittavan suhteesta on hyvin olennainen, kun kyse on pitkäkestoisesta seuruusta (vrt. myös Wagnerin ja Tagliamonten artikkelin esittelyyn edellä). Tätä aihetta on pohdittu paljon antropologiassa, jossa kenttätyöjaksot voivat olla vuosien mittaisia ja hyvinkin intensiivisiä.

Artikkelin pohjana ovat tutkijan omat kokemukset eräästä Pariisin lähiöstä, jossa hän on tehnyt kenttätyötä pohjoisafrikkalaistaustaisten nuorten parissa 
toistakymmentä vuotta 1990-luvun lopulta alkaen. Tutkimuksen luonne muuttui tutkittavien aikuistuessa, ja eri kenttätyöjaksoilla oli erilaisia painopisteitä. Pitkäkestoisen tutkimuksen myötä kirjoittajalla oli mahdollisuus havainnoida, miten tutkittavien aikuistuminen ja elämän käännekohdat, kuten avioituminen ja vanhemmuus, vaikuttivat heidän kielenkäyttöönsä. Tetreault tarkasteli erityisesti sitä, miten les cités -nimisen ${ }^{1}$ puhetyylin käyttö muuttui aikuistumisen myötä. Hän oli kiinnostunut erityisesti siitä, miten vanhemmat nuoret sosiaalistivat nuorempiaan tähän tyyliin ja toisaalta aikuistuessaan toisiaan pois sen käytöstä. Tutkija uskoo, että juuri pitkäaikainen etnografia on olennainen keino päästä käsiksi siihen, miten puhujien kielelliset normit ja käytänteet muuttuvat iän ja yhteisössä tapahtuvien muutosten myötä. Näin on mahdollista tunnistaa, milloin on kyse sukupolvimuutoksesta, milloin koko yhteisöä koskevasta muutoksesta.

Fennistisissä reaaliaikatutkimuksissa etnografista otetta ei ole toistaiseksi hyödynnetty. Keruukertojen välit ovat olleet pitkiä, ja haastattelijat ovat useimmiten olleet eri kerroilla eri henkilöitä (esim. Kurki 2005: 60-63; Mustanoja 2011: 31-33; Lappalainen ym. tulossa). Lähimmäksi Tetreaultin tutkimusta tulevat Palanderin (esim. 2016, 2018) tutkimukset, joissa tutkija on pitänyt pääinformanttiinsa ja hänen perheeseensä yhteyttä jo vuosikymmeniä.

Teoksen päättää Hélène Blondeaun artikkeli, jossa hän vertailee sosiolingvististen paneelitutkimusten sekä toisen kielen omaksumista koskevien pitkittäistutkimusten termistöä ja näkökulmia. Toisen kielen omaksumisen tutkimukseen on vaikuttanut ensikielen kehitystä koskeva tutkimus, ja usein näitä kielenoppimis-

1. Les cités tarkoittaa aluetta, tässä yhteydessä Pariisin esikaupunkialuetta, jollaisella tutkittavat asuvat. prosesseja on vertailtu keskenään, yhtenä esimerkkinä niin sanottu kriittisen iän hypoteesi. Kielen oppimista on tyypillisesti tarkasteltu vertailemalla erilaisia oppijaryhmiä, jotka ovat opiskelleet kieltä eripituisia aikoja. Tyypillisiä muuttujia ovat olleet se, kuinka kauan kieltä on opiskeltu ja kuinka monennen polven maahanmuuttaja on kyseessä. Sosiolingvistiikassa tällaista poikittaistutkimusta vastaa näennäisaikatutkimus.

Varsinaisia pitkittäistutkimuksia toisen kielen omaksumisen tutkimukseen on tullut vasta viime vuosina. Kyse on ollut esimerkiksi samojen kielenoppijayksilöiden seurannasta. Yleensä näissä tutkimuksissa on ollut enemmän kuin kaksi aikapistettä ja seuranta-aika on ollut vain muutamia kuukausia, korkeintaan joitakin vuosia. Tutkimus on ollut enimmäkseen laadullista, ja se on kohdistunut pieneen informanttijoukkoon (ks. suomalaisesta kontekstista esim. Savijärvi 2011). Erot sosiolingvistisiin paneelitutkimuksiin ovat siis monessa suhteessa ilmeisiä, vaikka sama ajatus puhujayksilöiden seuraamisesta on mukana molemmissa. Sen sijaan sosiolingvistisille trenditutkimuksille ei kielenoppimisen tutkimuksesta löydy suoraa vastinetta.

Lopussa Blondeau toteaa, että aika on ollut keskeinen elementti molemmissa suuntauksissa mutta eri syistä. Ajan vaikutusta kielelliseen variaatioon ja muutokseen on tutkittu samantapaisilla metodologisilla erotteluilla mutta eri terminologiaa ja erilaista empiiristä metodologiaa käyttäen. Siksi tutkimusten keskinäinen vertailu on ollut vaikeaa. Sekä sosiolingvistiikassa että kielenoppimisen tutkimuksessa kehityssuunta on ollut sama, poikittaistutkimuksista pitkittäisiin. Blondeau pohtii, miten nämä kaksi tutkimusalaa voisi linkittää ja päästä tutkimaan kielenoppijoiden sosiolingvistisen kompetenssin kehittymistä. Ensi askelia tässä on jo otettu. Kielenoppimisen tutkimuksissa on vielä kuilu pääasiassa 
kvantitatiivisen ja kokeellisen poikittaistutkimuksen ja kvalitatiivisesti painottuneen pitkittäistutkimuksen välillä. Blondeaun mukaan nämä erilaiset tarkastelutavat ovat viime aikoina kuitenkin lähentyneet toisiaan.

\section{Lopuksi}

Pitkittäistutkimukset nostavat esiin monia teoreettisia kysymyksiä. Esimerkiksi edellä esitelty Reuboldin ja Harringtonin tutkimus vahvistaa jo varsin laajalle sosiolingvistien yhteisössä levinnyttä näkemystä siitä, että kielenmuutos jatkuu läpi elämän, lapsuusiästä vanhuuden päiviin. Cukor-Avilan ja Baileyn tutkimus puolestaan havainnollistaa, että haastattelujen välillä on joka tapauksessa aina eroa, eikä kahta, piirrevariaation näkökulmasta samanlaista haastattelua ole mahdollista tavoittaa. Van Hofwegenin ja Wolframin artikkelissa ollaan niin ikään aivan perimmäisten kysymysten äärellä: miten muutosta lopulta mitataan? (Ks. myös Kurki 2005; Mustanoja 2011; Lappalainen ym. tulossa.) Kirjoittajat peräänkuuluttavatkin holistista lähestymistapaa paneelitutkimukseen. Näin päästäisiin käsiksi siihen, millainen on kokonaisvaltainen muutos idiolektissa ja varieteetissa. Varieteetti - samoin kuin idiolekti - on enemmän kuin yksittäisten piirteiden joukko.

Cukor-Avilan ja Baileyn artikkelissa kuvattu Springvillen projekti on luonteeltaan antropologinen, ja siinä korostuu sen pohtiminen, miten tutkijat voisivat osallistua tutkimansa yhteisön elämään mahdollisimman luontevasti. Muutoksen tutkimuksen kannalta ei mielestämme kuitenkaan voi kategorisesti todeta, että haastattelijan ja haastateltavan suhteen olisi pakko olla läheinen ja haastattelun mahdollisimman keskustelunomainen. Olennaisempaa on, että verrattavat aineistot ovat mahdollisimman samankaltaiset niin yleisten puitteiden kuin tilanteen muodollisuuden näkökulmasta.
Uusien paneelitutkimusten käynnistäjillä on tietysti vapaat kädet - ja ehkä paineitakin - monipuolistaa tutkimusasetelmia. Sosiolingvistisestä tutkimuksesta puuttuu tällä hetkellä tieto siitä, kuinka radikaalisti lähekkäiset, esimerkiksi päivän välein tehdyt haastattelut voivat erota toisistaan, vaikka haastattelija ja tilanteen ulkoiset puitteet pysyisivät samoina. Samoin puuttuu systemaattinen tieto siitä, kuinka suuri haastattelijan vaikutus lopulta on. Cukor-Avilan ja Baileyn mukaan informantit eroavat toisistaan myös siinä, kuinka paljon haastattelun kontekstilla ylipäätään on heidän kieleensä vaikutusta.

Reuboldin ja Harringtonin tutkimus muistuttaa, että arkistojen kätköissä on tallessa valtava määrä sosiolingvistiseen ja osittain myös laatunsa puolesta sosiofoneettiseen tutkimukseen soveltuvaa reaaliaika-aineistoa. Paneelitutkimusta ajatellen kiinnostavia tutkimuskohteita voivat olla esimerkiksi erilaiset kauan julkisuudessa toimineet henkilöt, kuten poliitikot, urheilijat, muusikot sekä radio- ja televisiotoimittajat, joiden puhetta saattaa löytyä erilaisista arkistoista ja internetistä pitkältä ajalta. Näitä aineistoja ei kuitenkaan ole alun perin suunniteltu tutkimuskäyttöön, ja metadataa voi olla saatavilla puutteellisesti. Suomen kontekstissa on myös todettava, että Yle on alkanut arkistoida tuotantoaan systemaattisesti vasta suhteellisen myöhään, 1980-luvulla. Cieri ja Yaeger-Dror nostavat artikkelissaan esiin yhteiskunnassa tapahtuneet muutokset, jotka yksilön kielessä ilmenevää variaatiota tulkittaessa on myös syytä huomioida: esimerkiksi poliittisten haastattelujen luonne on muuttunut vuosikymmenten kuluessa.

Monia suomalaisia reaaliaikatutkimuksia ei ole itse asiassa niiden ensi vaiheessa suunniteltu reaaliaikatutkimuksiksi (esim. Palander 2005: 22-23), vaan ajatus seuruusta on syntynyt vasta jälkikäteen. Kotimaisten kielten (tutkimus)keskuksen 
koordinoima seuruuhanke (ks. esim. Nuolijärvi \& Sorjonen 2005; Kurki 2005), jossa samojen puhujien ja puhujayhteisöjen seuraaminen on ollut alusta asti keskeinen tavoite, on tässä suhteessa ennemminkin poikkeus kuin tyypillinen tapaus. Paljon on olemassa myös yhden aikapisteen aineistoa, jolle olisi mahdollista kerätä jatkoa reaaliaikatutkimusta varten.

Wagner ja Tagliamonte nostavat artikkelissaan tarkasteluun tärkeitä digiajan kysymyksiä: Mitä seuraa siitä, että nykynuoret - ja -vanhemmatkin - liikkuvat sujuvasti verkossa ja tutustuvat aiempaa huomattavasti todennäköisemmin heistä tehtyihin tutkimuksiin? Näin tapahtuu siksikin, että yhä useampi tutkimus on nykyään avoimesti saatavilla. Kun tutkijoilla voi olla halua ja tarvetta julkaista tuloksia pitkän paneelitutkimuksen aikana, on puntaroitava, mitä tutkittaville kerrotaan ja miten tutkimusten raportointi voi mahdollisesti vaikuttaa tutkittavien kielelliseen käyttäytymiseen. Tutkittavien motivoimiseksi tutkijan on oltava valmis jonkinlaiseen avoimuuteen ja yhteistyöhön - paljastamaan tutkimuksen yksityiskohtia ja avaamaan myös omaa elämäänsä. Tämä on johtanut esimerkiksi siihen, että tutkijat ja tutkittavat ovat Facebook-kavereita, nimenomaan tutkittavien aloitteesta. Tämä on pakottanut Wagnerin ja Taglimonten pohtimaan myös sitä, mitä, miten ja kenelle he jakavat sosiaalisessa mediassa. Toisaalta Facebookin avulla tutkijat ovat pysyneet monin tavoin liikkuvien (usein nimeäänkin vaihtavien) tutkittaviensa jäljillä. Vaikka Facebook-kaveruus voikin tuntua ääriesimerkiltä, monessa artikkelissa (esim. Cukor-Avila \& Bailey ja Tetreault) korostuu tutkijan ja tutkittavien välisen yhteydenpidon tärkeys reaaliaikatutkimuksen aikana.

Samaan aikaan vastassa ovat eettiset ongelmat, nimittäin tutkittavien yksityisyyden turvaamiseen liittyvät haasteet, jotka eivät ole vieraita pioneeritut- kijoillekaan (ks. Sankoffin artikkelia). EU:n uuden tietosuoja-asetuksen myötä keskusteluun ovat nousseet tutkimuslupiin ja aineistojen hankintaan ja arkistointiin liittyvät kysymykset. Näistä olisi syytä saada kenttätyötä tekeville lingvisteille selkeät käytännön toimintaohjeet ja asiakirjamallit, jotta tahattomia tietosuojaloukkauksia ei pääsisi tapahtumaan ja jotta tutkijat voisivat keskittyä olennaiseen eli tutkimusaineistojen keruuseen ja niiden analysointiin. Wagner ja Tagliamonte kuitenkin aiheellisesti huomauttavat, että kaikille henkilöllisyyden salassa pysyminen ei ole tärkeää - päinvastoin osa haluaisi esiintyä nimellään ja saada näkyvyyttä.

Näkyvyys on kyllä mahdollista, sillä informantti voi halutessaan antaa luvan henkilötietojensa julkaisemiseen. Tosin hänellä on oltava mahdollisuus myös perua suostumus. Pelkkään luvanvaraisuuteen perustuva tutkimus voikin olla ongelmallista, ja henkilötietojen käsittelyyn olisi tutkijalla aina hyvä olla muitakin perusteita. Silti ympyrä on tavallaan sulkeutumassa murteiden seuruun aikaan, jolloin peräpohjalaismurteinen Eenokki Lapa-aho ja muut kielimestarit esiteltiin julkaisuissa syntymävuosien ja kuvien kera (ks. esim. Virtaranta \& Yli-Paavola toim. 1980). Myös meillä on vastaavia tuoreita kokemuksia: Sata suomalaista kielellistä elämäkertaa -tutkimushankkeen yliopistokaupunkeja keväällä 2019 kiertäneesssä näyttelyssä osa haastatelluista esiintyy omilla kasvoillaan, etunimellään ja äänellään (ks. https://blogs.helsinki. fi/1oosuomalaista/).

\section{HANNA LAPPALAINEN etunimi.sukunimi@helsinki.fi Lissa Mustanoja etunimi.sukunimi@tuni.fi}

Hanna Lappalainen on suomen kielen yliopistonlehtori Helsingin yliopistossa ja Liisa Mustanoja Tampereen yliopistossa. 


\section{Lähteet}

Brook, MARISA - JANKOWSKI, BRIDGET L. - Konnelly, LeX - Tagliamonte, SALI A. 2018: 'I don't come off as timid anymore'. Real-time change in early adulthood against the backdrop of the community. - Journal of Sociolinguistics 22 s. 351-374. https://doi-org.libproxy. helsinki.fi/10.1111/josl.12310.

Kuparinen, Olli 2018: Infinitiivien variaatio ja muutos Helsingin puhekielessä. - Virittäjä 122 s. 29-52. https://doi. org/10.23982/vir.65310.

Kurki, Tommi 2005: Yksilön ja ryhmän kielen reaaliaikainen muuttuminen. Kielenmuutosten seuraamisesta ja niiden tarkastelussa käytettävistä menetelmistä. Helsinki: Suomalaisen Kirjallisuuden Seura.

LAASANEN, Mıкко 2016: Näennäisaikametodin taustaoletusten teoreettista tarkastelua. - Virittäjä 120 s. 5-83.

Lappalainen, Hanna - Mustanoja, LiIsA - O’Dell, Michael (tulossa): Miten ja milloin yksilön kieli muuttuu? Helsinkiläisidiolektien muutos ja muutoksen tutkimuksen menetelmät. - Virittäjä.

Mustanoja, Liss a 2011: Idiolekti ja sen muuttuminen. Reaaliaikatutkimus Tampereen puhekielestä. Acta Universitatis Tamperensis 1605. Tampere: Tampereen yliopisto.

Nuolijärvi, Pirkko - Sorjonen, Marja-Leena 2005: Miten kuvata muutosta? Puhutun kielen tutkimuksen lähtökohtia murteenseuruuhankkeen pohjalta. Kotimaisten kielten tutkimuskeskuksen julkaisuja 133. Helsinki: Kotimaisten kielten tutkimuskeskus.
Palander, Marjatta 2005: Lapsuudesta keski-ikään. Seuruututkimus itäsavolaisen yksilömurteen kehityksestä. Helsinki: Suomalaisen Kirjallisuuden Seura.

_ 2016: Savolaismurteen muutos. Kahden sukupolven seitsenvuotiaiden puhekieli. - Sananjalka 58 s. 89-111.

2018: Savolaismurteiden muuttuva morfosyntaksi. Seuruukohteena neljän sukupolven perhe. - Sisko Brunni, Niina Kunnas, Santeri Palviainen \& Jari Sivonen (toim.), Kuinka mahottomasti nää tekkiit. Juhlakirja Harri Mantilan 6o-vuotispäivän kunniaksi s. 165-192. Studia humaniora ouluensia 16. Oulu: Oulun yliopisto. http://urn.fi/ urn:isbn:9789526221120.

Paunonen, Heikni 2005: Helsinkiläisiä puhujaprofilleja. - Virittäjä 99 s. 162-20o.

— 2018: Tornion murteesta meänkieleen. Reaaliaikainen tutkimus Ruotsin Ylitorniolta 1966-1992. - Sisko Brunni, Niina Kunnas, Santeri Palviainen \& Jari Sivonen (toim.), Kuinka mahottomasti nää tekkiit. Juhlakirja Harri Mantilan 6o-vuotispäivän kunniaksi s. 15-161. Studia humaniora ouluensia 16. Oulu: Oulun yliopisto. http://urn.fi/ urn:isbn:9789526221120.

SAVIJÄrvi, Marjo 2011: Yhteisestä toiminnasta yhteiseen kieleen. Keskustelunanalyyttinen tutkimus toisen kielen oppimisesta kielikylpypäiväkodin arkitilanteissa. Helsinki: Helsingin yliopisto.

Sundgren, Eva 2004: Språklig variation och förändring. Exemplet Eskilstuna. Lund: Studentlitteratur.

Virtaranta, Pertti - Yli-Paavola, JA A K KO (toim.) 1980: Suomen murteet. Suomi 119: 1. Helsinki: Suomalaisen Kirjallisuuden Seura. 